Journal of Education and Vocational Research

Vol. 4, No. 7, pp. 205-208, July 2013 (ISSN 2221-2590)

\title{
Leadership Succession and Strategic Change in Nigerian Commercial Banks
}

\author{
*Abdulkadir Musa Badara, Husna Bt Johari, Tan Fee Yean \\ School of Business Management, College of Business University Utara Malaysia \\ *abdulkadir_musa@yahoo.co.uk
}

\begin{abstract}
The relationship between leadership succession and strategic change is generally examined. However, more needs to be covered in the area. The paper proposed to provide a framework that will examine the relationship between leadership succession and strategic change in the Nigerian Banking sector. The model will help to a better understanding of the direct relationship between leadership succession and strategic change, hence, regulatory agencies, shareholders and board members, as well as management team will benefit from the study outcome.
\end{abstract}

Keyword: Leadership succession, strategic change, commercial banks, Nigeria

\section{Introduction}

Banks are very important and useful to the growth and development of every economy because of the financial service they provide. The active and operational performance of the banking sector over time is an index of financial stability in any nation (Kolapo, Ayeni \& Oke, 2012). Market participants are required to make changes in their day-to-day operational activities above local to global competitiveness, because of the progressive globalization of financial markets. This scenario made several banks in many nations to grow in terms of speed, reduction in expenditure, quality in customer service and enhance profitability performance (Randle, 1995). However, Sanusi (2012) stated that the Banking industry generally, is more than just an institutions that smooth the progress of payments and extend credit. It has comprises the entire functions that direct valid resources to their final consumer. Hence, it is the most important system of a market economy, which consists of a number of different, mutually reliant, components all of which are important to its efficient and well-organized operation. Thus, these components include financial mediators such as banks and insurance companies, which operate as principal agents for presumptuous liabilities and acquiring claims. The market is another component where by the material goods are exchanged, whereas infrastructure is the third component, which is essential for the successful communication of mediators and markets. The three components are inextricably entwined (Sanusi, 2012). Furthermore, Banks require system of payment for infrastructure to swap claims steadily and markets in order to dodge the risks arising from their intermediation activities (Sanusi, 2012). Therefore, the banking sector functions very well and successfully when there is a healthy and sufficient payments systems infrastructure. Additionally, the anxiety to guarantee a better banking system by the Central Bank is underscored by the significant roles of banks in nationwide economic development. For example, Banks mobilizes savings for the purpose of investment, which later leads to employment and growth.

The actual area, that is the industrious part of the economy, depends deeply on the banking industries for credit. Government also raises capital through the banking system to sponsor its developmental programmes and strategic objectives (Sanusi, 2012). Nigerian banking industry plays a very significant role to economic development (Sophia, 2011). According to Nzotta (2004) banks are part of the Nigerian financial system that has the ability to channel scarce resources from surplus economic units to deficit units; they also exert a lot of impact on the pattern and trend of economic development through their lending and deposit mobilization activities. In the same vein Abdullahi (2002) reveals that the banking industry in particular plays a crucial role in the economic growth by mobilizing savings and directing them for investment especially in the real sector, which increases the provision of good and service produce in the economy, hence national output increases and the level of employment also improve. Most of the major issues attributed to strategic changes in Nigerian banks are, the rate of doing business transaction in Nigeria is very high when compared with other developed nations or a number of up-coming and developing countries due to the poor state of 
infrastructure facilities (Sanusi, 2012). Additionally, is that the high developmental rates recorded in the last five years have not been included, indicating that this has not transformed into better growth. However, Sanusi (2012) says that the scenario is responsible for the high level of poverty and unemployment, which unavoidably affected the low banking practice in the country.

\section{Literature Review}

Concept of Leadership Succession: Which can see Leadership succession, as a process or pivotal act in the history of a company a new leader, takes the place of a retiring leader and inherits all the rights and responsibilities of the company position (Hutzschenreuter, 2012). Succession can also be defined as the origin of strategic orientation Haddadj (2011). According to Ndofor et al. (2009), Leadership successions are warning sign in organizations' histories, frequently trumpeted by the business push as precursors to strategic reorientations and improved productivity. Chief executive Succession is a process, which provides a chance for existing power relationships to be altered, for new strategic system to be introduced and for strategic change to occur (Boeker, 1997). For the purpose of these paper leadership successions is the process whereby a new leader take place of an outgoing leader and transform the organization from bad position to good condition. Chief executive officer (CEO) succession occurs when a firm or organization declare the selection of a new CEO (Graffin, Carpenter, \& Boivie, 2011). The declaration of CEO change transfers a very strong sign that the person accountable for the poor performance is about to be replaced and that his successor can guide the firm to success (Liu, Valenti \& Yu, 2011).

CEO selections are normally made behind closed doors, and information about the process how board members choose CEO is hardly disclosed (Shen \& Cannella, 2003). This helps the leadership of a firm to make decision on how, what and when information is shared. Because this procedure take place in secret, members of the financial press reporting the event, as well as shareholders, do not have access to information pending when organization leaders decided to make it public (Graffin et al., 2011). However, boards' members look forward to the newly appointed leader to make changes and enforce a mandate to improve the organization's vision, mission, goals and strategies (Helfat \& Bailey, 2005). In the same vein when chief executive or leadership succession occurs, a new person, with new perspectives and skills including new ideas on the range of markets in which a firm should compete and takes over the organization. Hence since succession often means change in the process or the way in which a firm operates, it carries with it the possibility that existing norms and expectations within the organization will be upset (Boeker, 1997). However, there was no succession in the Nigerian-banking sector but the sacking of eight chief executive directors who were not performing by the central bank governor brought about leadership succession and strategic change in the Nigerian banking sector (Sanusi, 2010).

Strategic Change: Several scholars have defined strategic change in differences ways for example, according to Hutzschenreuter, Kleindienst \& Greger (2012), strategic change refers to dissimilarities in form, value or state in an organization entity over a period of time that modifies the organization position with its environment. Zhang and Rajagopalan (2010), define strategic change as the disparity over time in a firm's form of resource distribution in a number of important strategic dimensions that drives ahead of industrywide changes in these dimensions. Strategic change can also refers to as the total change in a firm's way of resource allocation in a number of vital strategic dimensions (Finkelstein, 1990; Carpenter, 2000 \& Zhang 2006) In the same vein strategic change signifies a radical organizational change that is deliberately initiated by top managers, creating a change in key activities or structures that went beyond incremental changes to previous practices (Rajagopalan, 1997). For the purpose of this paper, strategic change can be defined as measures taken to achieve a desired objectives or differences that exist between company and its environment over a period of time, which alter the position of the company.

However, all organisations are now currently undergoing some kind of transformation in terms of changes. Most of these change programmes came up from management fads, which include; empowerment, cultural change, process of business engineering and total quality. Additionally, other change initiatives arise from the need for organisations to reposition themselves in the face of changing competitive conditions (Balogun, 2001). Strategic change was adaptive and mends for any firms or organization that suffered badly from a fragile strategic setting (Barker \& Duhaime, 1997). Most of the major issues attributed to strategic changes in 
Nigerian banks are, the cost of business transaction in Nigeria is very high when compared with other developed countries or some up-coming and developing countries due to the poor state of infrastructure facilities (Sanusi, 2012). Additionally, is that the high growth rates recorded in the last five years have not been included, indicating that this has not transformed into constant growth. However, (Sanusi, 2012) says that the scenario is responsible for the high level of poverty and unemployment, which unavoidably affected the low banking practice in the country. Furthermore, Sanusi (2010) noted that most of the banks in Nigeria have failed and are characterised with a lot of problems such as low turnover, low profit, high interest rate, weak corporate government, non-performing loans, poor internal controls and excessive risk taking.

Research Framework: The literature reviews show a direct relationship between leadership succession and strategic change. Thus, the framework suggests that, the aim of leadership succession is to initiate change in the organization.

$$
\text { Leadership Succession }
$$

Strategic Change

The theory of CEO life cycle introduced by (Hambrick \& Fukutomi, 1991) could be used in describing the relationship between leadership succession and strategic change. Thus drawing up on the theory of CEO life cycle by (Giambatista, 2004; Hambrick \& Fukutomi, 1991; Henderson, Miller \& Hambrick, 2006; Hutzschenreuter, Kleindienst \& Greger, 2012; Miller \& Shamsie, 2001; Staw, 1981) argued that chief executive officer that stay long on the throne will not bring change due to the long time experience and used to the system, he will therefore try to maintain the status quo. These phases are characterized by different method of leader thought and conduct and, as an addition, by different ways of strategic change.

However, some CEOs have large experience individually in negotiating acquisitions, while others did not have this kind of experience. Some CEOs have the skills and talent to give uplifting, inspiring speeches before large groups of people, while other CEOs cannot (Hambrick \& Fukutomi, 1991). The theory of CEO life cycle has clustered within one most important suggestion: Which stated that leaders that stayed longer are less expected to instigate strategic change (Finkelstein, Hambrick \& Cannella, 2009). Hence, this dispute is based on the declaration that inactivity grows with term. The outcome of the long-term leaders' struggle to instigate or initiate strategic change is a growing misalignment involving their organization and the external environment (Henderson et al., 2006). In view of that, whenever a new leader assumes office following a long term CEO more strategic change is needed so as to attain a balance between the company and the external environment, and vice versa. CEO life cycle theory draws on knowledge and inactivity to argue the dynamics of a leader's term. In the early era of CEOs, they start work by learning a strategy and the skills to realize it, thus by engaging in a great deal of conducting tests (Hutzschenreuter et al., 2012). As time goes on, CEOs will naturally acquire a lot of knowledge and experience about their businesses.

\section{Conclusion}

In this paper, effort has been made to provide a general overview of how leadership succession leads to strategic change in Nigerian commercial banking industry. Conceptual understanding of succession as well as change in an organization is also established. The paper provided a theoretical framework, which could serve as the reference model in the relationship between leadership succession and strategic change

\section{References}

Abdullahi, S. A. (2002). Distress in the Nigerian banking: A critical assessment of the nature,causes and extent. Bus Administration, 2, 135-154.

Barker-III, V. L. \& Duhaime, I. M. (1997). Strategic change in the turnaround process: theory and empirical evidence. Strategic Management Journal, 18(1), 13-38.

Balogun, J. (2001). Strategic change. Management Quarterly, 10, 2-11.

Boeker, W. (1997). Strategic change: The influence of managerial characteristics and organizational growth. Academy of Management Journal, 40(1), 152-170. 
Finkelstein, S. \& Hambrick, D. C. (1990). Top management team tenure and organizational outcomes. Administrative Science Quarterly, 35, 484-503.

Finkelstein, S., Hambrick, D. C. \& Cannella, A. A. (2009). Strategic leadership: Theory and research on executives, top management teams, and boards: Oxford University Press, USA.

Giambatista, R. C. (2004). Jumping through hoops: a longitudinal study of leader life cycles in the NBA. The Leadership Quarterly, 15(5), 607-624.

Graffin, S. D., Carpenter, M. A. \& Boivie, S. (2011). What's all that (strategic) noise? anticipatory impression management in CEO succession. Strategic Management Journal, 32(7), 748-770.

Haddadj, S. (2011). CEO succession and strategic change and orientation in small and medium-sized firms: New perspectives from France. Journal of Applied Business Research (JABR), 15(3), 81-98.

Hambrick, D. C. \& Fukutomi, G. D. (1991). The seasons of a CEO's tenure. Academy of Management Review, 16(4), 719-742.

Helfat, C. E. \& Bailey, E. E. (2005). External succession and disruptive change: heirs-apparent, forced turnover and firm performance. Strategic Organization, 3(1), 47-83.

Henderson, A. D., Miller, D. \& Hambrick, D. C. (2006). How quickly do CEOs become obsolete? Industry dynamism, CEO tenure, and company performance. Strategic Management Journal, 27(5), 447-460.

Hutzschenreuter, T., Kleindienst, I. \& Greger, C. (2012). How new leaders affect strategic change following a succession event: A critical review of the literature. The Leadership Quarterly, 23, 729-755.

Kolapo, T. F., Ayeni, R. K. \& Oke, M. O. (2012). Credit risk and commercial banks' performance in Nigeria: A panel model approach. Australian Journal of Business and Management Research, 2(2), 31-38.

Liu, Y., Valenti, M. A. \& Yu, H. Y. (2011). Presuccession Performance, CEO Succession, Top Management Team, and Change in a Firm's Internationalization: The Moderating Effect of CEO/Chairperson Dissimilarity. Canadian Journal of Administrative Sciences/Revue Canadienne des Sciences de l'Administration, 29(1), 67-78.

Miller, D. \& Shamsie, J. (2001). Learning across the life cycle: Experimentation and performance among the Hollywood studio heads. Strategic Management Journal, 22(8), 725-745.

Ndofor, H. A., Priem, R. L., Rathburn, J. A. \& Dhir, A. K. (2009). What does the new boss think?: How new leaders' cognitive communities and recent top-job success affect organizational change and performance. The Leadership Quarterly, 20(5), 799-813.

Nzotta, S. (2004). Money, Banking and Finance: Theory and Practice. Owerri: Hudson-Jude Nigeria Publishers.

Rajagopalan. N. S. G. (1997). Toward a theory of strategic change: a multi-lens perspective and integrative framework. Academy of Management review, 22, 48- 79.

Randle, W. M. (1995). Delivering the future: Redefining the role of banks in new competitive environment. Bank Management, 7(1), 45-58.

Sanusi, S. L. (2012). Banking reform and its impact on the Nigerian economy. Lecture presented at the University of Warwick's Economic Summit, UK, Feburary, 17.

Shen, W. \& Cannella, A. A. (2003). Will succession planning increase shareholder wealth? Evidence from investor reactions to relay CEO successions. Strategic Management Journal, 24(2), 191-198.

Sophia, A. E. A. J. M. (2011). Mergers and Acquisitions in the Nigerian banking Industry. An Explorative Investigation Medwell Journals, 6(3), 213- 220.

Staw, B. M. (1981). The escalation of commitment to a course of action. Academy of Management Review, 6(4), 577-587.

Zhang, Y. (2006). The presence of a separate COO/president and its impact on strategic change and CEO dismissal. Strategic Management Journal, 27(3), 283-300.

Zhang, Y. \& Rajagopalan, N. (2010). Once an outsider, always an outsider? CEO origin, strategic change, and firm performance. Strategic Management Journal, 31(3), 334-346. 